\title{
Realism and Idealism as Political Concepts
}

\author{
Emilia Icoska* \\ Faculty of law- Kicevo, Republic of Macedonia
}

*Corresponding Author: Emilia Icoska, Faculty of law-Kicevo, Republic of Macedonia

\begin{abstract}
This paper will take in mind two, according to me most important political conceptions that give clear understandings of the meaning of the state against the international community and after the place of the country in the international community.

Classical realism sees the country as unique subject. Subject that is self-sufficient and does not need interaction with other states (subjects). For these reasons realism as concept will be explained in the paper because today does not lose its relevance. His opponent idealism criticizes realistic thoughts and underlines that there are other subjects like INGOs.
\end{abstract}

Keywords: Realism, Neo-Realism, Idealism, Neo-Idealism, Concept

\section{INTRODUCTION}

The science of international politics and international relations will take always in mind these philosophical concepts that are for great benefit to grasp their subject of interest. Some of these concepts are younger and some older but they allude to a specific event in the international community of the past until today and certainly see the furthest future.

When it comes to the "clash" between realism and idealism it is to admit that this is a conflict that has its historical lines, and today is interesting while studying the international politics. As the most representative of realism is considered Hens Morgenthau, whose theory is mostly identified with that of Hobbes' understanding of the world where the government is the natural milieu of anarchy, a struggle of all against all, and the desire for power. Morgenthau draws the conclusion that political realism believes in politics and society too much whose explication lays in the human nature of the man. Classical realism sees the country as a single entity in international relations (realpolitik), which is a major foreign policy goal of having the states as the primary entity in the international relations. For these reasons realism as detailed concept will be presented in the topic because today does not lose its relevance. His opponent idealism criticises the thoughts of relistics and implements other subjects like the INGOs. Among the most prominent philosophers of idealism and the followers of this tradition of thought can be distinguished: Adam Smith, Immanuel Kant, John Stuart Mill, Woodrow Wilson, John Hobson and John Maynard Keynes.

\section{REAliSM AS A POWER STRUGGLE ${ }^{1}$}

According to Morgenthau the struggle for power takes major importance in international relations. People often considerate the fact that someone wants to attack and destroy them so they must continually be prepared to kill, to protect themselves. This basic human instinct guide states. Realists argue that rivalry and disaccord between nations in some forms are always present. Just as the interests guide the behavior of people, the national interest governs the foreign policy of sovereign states. So through conflicts in international relations is expressed the struggle for power. Realists do not take into account the manners because their national objective must be achieved in any cost. Realism argues that the international community is in a stage of anarchy and its key actors- states cannot overcome their own interests because for the interests of the community. This concept is generally associated with lack of morality and ethics in international politics that may be presented by the states that do not correspond with those in the international community. So the "reason d'etat" is more prevalent and is usually incompatible with the common "raison" in the international community. Realism propagates the strength of military power against other countries, apart from the idealism that gives importance to economic connectivity and the role of international organizations.

\footnotetext{
${ }^{1}$ Tonovski 2008
} 


\section{Six PRINCIPLES OF REALISM ACCORDING TO MORGENTHAU ${ }^{2}$}

According to the first principle, policy and society in general are driven by laws in whom it is presented the human nature. For the improvement of the society first it is necessary to understand the rights where the society lives. Thus you need to determine the precise facts and to give them meaning through the reasons on which they arise. To give meaning to the actual and material foreign policy there must be approach with the political reality and with some rational thinking. Realism in the center of thinking puts the quality of the man who can simultaneously be both good and bad.

The second principle concerns that international politics have interest defined through the prism of power. Politics is understood as an autonomous sphere of actions and understandings different from other areas such as economic, ethical or religious. This assumption of power allows to connect the justification of current, past or future actions that were or will be taken in the future. We can understand the actor on the political stage only analyzing his actions always delegated through his desire for power. The concept of interest defined as power includes intellectual capacity of observer to understand the movements of the political entity departing through the prism of his interest. Knowing the motives of behavior it leads directly to the reasons why foreign policy has taken a certain direction. Perhaps it can be difficult to untangle some future political events but surely analysts have found an answer to the procedures of past policies of states, empires and other structures certainly not forgetting their desire for power.

The third principle of realism by Morgenthau suggests that interest through the power is an objective category and generally applicable, but it is not fixed once and for all. Interests directly motivate human activities. Thus, images of the world in the past created through such ideas often serve as an example that the interest is dynamic movement in where the interest prevails.

The fourth principle analyzes the morality and the political action. The fourth principle suggests that there is a tension between the moral command and the need for successful political action. Realism suggests that universal moral principles cannot be supported through the activities of the States but they must be filtered through specific temporal and local circumstances. One can at any time shoot out the side of morality even though it is contrary to the world but the state has no right to do that. Both subjects the man and the state should condemn political action by universal moral principles as it does idealism. It is impossible to have political morality without wisdom.

The fifth principle is that political realism does not identify the moral aspirations of a particular nation with the moral rights that would lead the world. Few countries were able to transcend traditional immoral temptations in terms of moral purposes in the world. To know what is morally right within the nation-state is something quite different from knowing what is right and wrong in the relations between states.

The sixth principle speaks of the political realist who has to get closer to the legal and moral point of view of international politics. The legal is what the policy is in accordance with the rules of law, while the moral is what the policy is in accordance with moral principles. Furthermore realists defend the autonomy of political thought in the direction that man is a combination of economic man, further political, moral, religious. If only political person is a beast, or if he is only moral he would be lunatic with lack of wisdom.

\section{NEO-REALISM}

Neo-realism as a political conception occurs later than realism when realists recognize that states need each other to communicate. Such collaborations are not due handshakes for global goals, but aim to selfish interests of countries to realize their own ideas. States decide, in large part because of economic interests to create some joint steps with other countries that they consider as economic interests. Yet such cooperation is a purely national, self-interested and is ideal for re-raising the power of the state in where lacks morality, honesty, and in the foreground there is selfishness and fight for supremacy over the other and their own interests.

\section{IDEALISM}

Idealists firmly believe that the goodness of human nature will prevail over what has emerged in the world and there will be a situation in which there will be no more wars, imbalances and tyranny. So it emerges new world with reason, science and education. Idealism is a picture of future international

\footnotetext{
${ }^{2}$ Morgenthau, 1978 
relations realized from powerful policies and violence. Idealism argues that international organizations proclaiming respect between nations will pave the road to a world free of conflict and war. The main point that distinguishes the realism of the idealism is the problem of power that is particularly emphasized by realists. For idealists morale is crucial and they aim for it to achieve international peace and cooperation. Throughout history as organizations that created respect for the law war were the League of Nations, Kellogg-Briand- pact. They had common interests and limited the war and states begun to cooperate each other in non-military way.

\section{NEO-IDEALISM ${ }^{3}$}

Neo-idealism is the latest variant of the classic paradigm, which highlights the prospects for interstate cooperation in world politics. Although largely neo-idealism focus on the role of international regimes to improve cooperation between state that are conceived as selfish. Functionally this concept is conceived as intra-cooperation between international governmental organizations to improve the standards of each country and implement standards of good functioning of the global community. The discussion of neo-idealism would be the introduction of common international standards in order to improve the global challenges and problem and their adoption that should touch to countries and improve certain state parameters within them. Such settings imply a direct and unbreakable link between the state and the international community for any changes in one of them that will input changes in perfect reciprocity to the other.

\section{CONCLUSION}

Idealism and realism as concepts are diametrically opposed but today are widely used when we want to understand international relations and international politics. These concepts offer practical knowledge that none of them is completely independent and self-sufficient, at least in an international community that is today. Analyzing them through practical application in the international community, today can be said that both are inter- dependent each other because the country remains the primary subject in international relations. You see today's international community contains an element of realism -the state and international relations of idealism. Yet we can emphasize that the power of the states is highlighted only in certain states, but not in all. But is also emphasized other "power" that of the international organizations.

\section{REFERENCES}

[1] Tonovski G. "Definition, features and subject to international politics" - Authorized lectures 2008

[2] Hans J.Morgenthau, Politics Among Nations: The Struggle for Power and Peace, Fifth Edition, Revised, New York: Alfred A. Knopf, 1978

[3] Meaning, nature, scope and approaches to international policy

[4] Henderson E.A. Neoidealism and the democratic peace, Jurnal of Peace Research 2015

\section{AUTHORS' BIOGRAPHY}

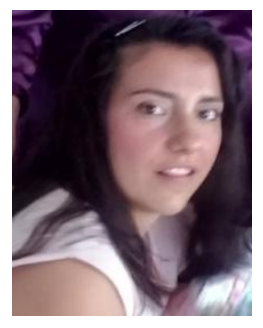

Emilija Icoska, was born in 1989 in Bitola, Republic of Macedonia. She finished high school in Bitola at the Gymnasium Josip Broz Tito. She graduated undergraduate law studies at the Faculty of Law in Kichevo and obtained a Bachelor of Law degree. She completed her master studies in Bitola at the Faculty of Law - Kichevo, where she obtained a Master's Degree in Law,- International Law. Currently, doctoral studies in International Law and Politics are underway at the Faculty of law-Kicevo.

Citation: Emilia Icoska. "Realism and Idealism as Political Concepts". International Journal of Managerial Studies and Research (IJMSR), vol 6, no. 11, 2018, pp. 43-45. doi: http://dx.doi.org/10.20431/ 2349-0349.0611004.

Copyright: (C) 2018 Authors. This is an open-access article distributed under the terms of the Creative Commons Attribution License, which permits unrestricted use, distribution, and reproduction in any medium, provided the original author and source are credited.

\footnotetext{
${ }^{3}$ Henderson 2015
} 